\title{
Mercury Removal from Aqueous Solution by Mixed Mineral Systems I. Reactivity and Removal Kinetics
}

\author{
D.E. Egirani ${ }^{1}$, A.R. Baker ${ }^{2}$ J.E. Andrews ${ }^{2}$ \\ ${ }^{1}$ Faculty of Science, Niger Delta University, Wilberforce Island, Nigeria \\ ${ }^{2}$ School of Environmental Sciences, University of East Anglia, Norwich, United Kingdom
}

\begin{abstract}
This study investigates the reactivity and removal kinetics of arsenite on mixed mineral systems from aqueous solution related to contaminated waters. The sorbents used were kaolinite, montmorillonite, goethite, and their mixtures. The effects of, proton coefficient, and sorption kinetics were studied at room temperature $(23 \pm 2 \circ \mathrm{C})$. Reactivity studies demonstrate enhancement of proton coefficient and the acidity of reactive sites by mixed mineral systems except for kaolinite-montmorillonite, thus increasing mercury removal by proton exchange. Kinetic studies demonstrate two- phase reactions attributed to outer sphere complexation and inner sphere complexation. In the first-phase reaction, mineral mixing based on our empirical model decrease the mass transfer rates for kaolinite-montmorillonite and montmorillonite-goethite, not affecting kaolinite-goethite. For the second-phase reaction, mineral mixing did not change the mass transfer rates for the mixed mineral systems except for montmorillonite-goethite. The behaviors of the mixed mineral systems in mercury sorption suggest that different reactive sites were involved at the onset of sorption, with reactions and sorption ending with inner-sphere complexation. Differences between actual and theoretical \% sorption progressed from negative to positive for all mixed minerals as contact time was increased. This means that increase in contact time during $\mathrm{Hg}$-sorbent interaction could help increase mercury removal based on mineral mixing.
\end{abstract}

Keywords: mercury, removal, reaction, kinetics, mixed mineral systems.

\section{Introduction}

Mercury poses an environmental and human threat due to its toxicity at low concentrations. It occurs in three forms namely $\left(\mathrm{Hg}^{\mathrm{o}}\right),\left(\mathrm{Hg}^{2+}\right)$ and $(\mathrm{HgP})$ and possesses high toxicity, volatility. Mercury bioaccumulates in the environment and creates neurological health impact [1]. Moreover, it appeared as a critical and chronic problem because it can easily be transformed into methyl mercury, an organic form, by bacteria in bottom level sediments which is taken up by organisms more rapidly and is much more toxic and stable than inorganic form [2].

Mercury and its compounds recognized as dangerous and insidious poisons and can be adsorbed through the gastrointestinal tract and also through the skin and lungs [3] which is stored in the liver, kidneys, brain, spleen and bone leading to development of carcinogenic, mutagenic, teratogenic and also promotes several health problems, tyrosinemia, paralysis, serious intestinal and urinary complications, dysfunction of the central nervous system and in more severe cases of intoxication, death. The severity of mercury toxicity was recognized in the late 1950s and 1960s because of an environmental tragedy in Minamata Bay, Japan, where hundreds of individuals suffered from mercury poisoning (Minamata disease) [4-5]

As a common heavy metal, mercury has been used in medical treatment and industry, but its toxic properties for human health and ecosystem have attracted increasing attention [6-8]. Sorption kinetic experiments revealed that mercury sorption is a relatively rapid process, where film diffusion and intra-particle diffusion play an important role. The US Environmental Protection Agency (USEPA) prepared a list of 129 organic and inorganic pollutants found in wastewater that constitute serious health hazards [9] This Priority Pollutants List includes thirteen elements: $\mathrm{Sb}, \mathrm{As}, \mathrm{Be}, \mathrm{Cd}, \mathrm{Cr}, \mathrm{Cu}, \mathrm{Pb}, \mathrm{Hg}, \mathrm{Ni}, \mathrm{Se}, \mathrm{Ag}, \mathrm{Tl}$ and $\mathrm{Zn}$ [10-12].

For successful treatment of water containing mercury using mineral systems, a full understanding of the reactivity and the kinetic reaction partners to the reactive sites of mercury sorbents is required [13-14].The removal of mercury from aquatic systems is controlled by the speciation, mobility, ionic size of the sorbing ions, sorbate composition, sorbent solubility, sorbent particle size, sorbent surface charge, surface area of the mineral sorbent, solution dilution and $\mathrm{H}+/-$ M exchange stoichiometry [15-16].

The sorption of a solute present in a solid-solution system is usually assumed to consist of four consecutive steps: external mass transfer of sorbate molecules across the boundary liquid film, binding of sorbate molecules on the active sites on the surface of the sorbent, intra-particle diffusion of sorbate molecules, and sorption of sorbate molecules on the active sites distributed within the sorbent particles. Reactivity of clay particles are associated with $\mathrm{OM}, \mathrm{Fe}$ or $\mathrm{Al}$ oxides [17-18] and combined with elevated temperatures and acidic $\mathrm{pH}$ (4-5) favor geochemical conditions and nutrient stocks favorable for $\mathrm{Hg}$ bacterial methylation [19]. The 
rapid detection and removal of $\mathrm{Hg}^{2+}$ from pollutants are dependent on a full understanding of the reactivity and removal kinetics of mercury in aqueous solution [20-25].

Several methods have been established in the treatment of mercury contaminated water. Some of these techniques include bamboo charcoal, apatite IITM, iron-based sorbents, diperiodatocuprate(III) coordination solution, malt spent rootlets, bacillus cereus, modified $\mathrm{Fe}_{3} \mathrm{O}_{4}$, flocculation method, complexation by dissolved organic matter, heterogeneous photocatalysis with $\mathrm{TiO}_{2}$, alginate and pectate [[26-35]. Others have reviewed the technologies for removing mercury in aqueous solution [36]. However, some of these new techniques are rather expensive for limited size water treatment systems situated in rural communities and the reactivity and removal kinetics require further investigation. Consequently, innovative cost-effective treatment processes are urgently needed. One of such emerging method is the use of mixed mineral systems of clays and hydroxide(s). Mixed mineral systems that could be applied for mercury removal from contaminated water are readily available locally.

\subsection{Theoretical models and isotherms}

To addresses the reactivity and removal kinetics involved in sorbent-sorbate interaction, a theory is designed to explain and predict the behavior of mineral-Hg interactions. Adsorption isotherms give a quantitative relationship between the solute concentration in the solution and the amount of solute adsorbed per unit mass of the adsorbent surface at equilibrium conditions. Langmuir, Freundlich, Dubinin-Radushkevich (DR) are the commonly used isotherms [37]. In the present study, an empirical model derived from Freundlich isotherm model was chosen.

Detailed system characterization and an empirical model involving the distribution coefficient (Kd) as used in this paper are provided elsewhere [38]. $\mathrm{Kd}(\mathrm{L} / \mathrm{kg})$ was calculated from the Freundlich model equation,

$S=K d C^{N}$

where $\mathrm{S}$ is the sorbed concentration $(\mu \mathrm{g} / \mathrm{kg}), \mathrm{Kd}$ is the distribution coefficient, $\mathrm{C}$ is the equilibrium concentration $(\mu \mathrm{g} / \mathrm{l})$, and $\mathrm{N}=1$ is a chemical-specific coefficient derived from the slope of the plot. The empirical model to address the mineral-Hg interactions is given:

$$
K d_{\text {total }}=K d_{\text {total }}=\frac{K d_{1}+K d_{2}+K d_{n}}{n}
$$

where $\mathrm{Kd}_{\text {total }} 1$ is the theoretical distribution coefficient for a $1: 1$ mixed suspension, $\mathrm{Kd}_{1}$ is the distribution coefficient for first single mineral suspension, and $\mathrm{Kd}_{2}$ is the distribution coefficient for second single mineral suspension, $\mathrm{Kd}_{\mathrm{n}}$ is the distribution coefficient for $\mathrm{n}$ number of mineral suspensions and $\mathrm{n}$ is the number of mineral suspensions.

The simple empirical model used for the partitioning of a sorbed mercury contaminant between single mineral phases and mixed mineral phases is based on the assumptions that the following could account for differences between single and mixed mineral sorption:

1. Secondary mineral phase developed during sorbate-sorbent interaction .

2. Components of minerals in the mixed mineral suspension acted as chemisorbed species and not as individual networks. 3. differential mass of mixed and single mineral phases.

The difference between the actual sorption and the theoretical sorption was used to clarify the effects of mineral mixing on $\mathrm{Hg}$ (II) sorption. Mineral mixing is said to (a) enhance $\mathrm{Hg}$ (II) removal where the difference is positive; (b) depresses or attenuate $\mathrm{Hg}(\mathrm{II})$ removal where the difference is negative; and (c) have no effect on $\mathrm{Hg}$ (II) removal where no difference exist between $\mathrm{Hg}$ (II) sorbed and theoretical $\mathrm{Hg}$ (II) sorption.

The difference between the actual $\mathrm{Kd}$ and the theoretical $\left(\mathrm{Kd}_{\text {total }}\right)$ was used to clarify the effects of mineral mixing on $\mathrm{Hg}$ removal. Mineral mixing is said to (a) enhances $\mathrm{Hg}$ removal where the difference is positive; (b) attenuate $\mathrm{Hg}$ removal where the difference is negative; and (c) have no effect on $\mathrm{Hg}$ removal where no difference exist between the actual $\mathrm{Kd}$ and theoretical $\mathrm{Kd}$ :

$$
\Delta K d=K d-K d
$$

\section{total}

For the reactivity and removal kinetic studies, the empirical model for the mixed mineral systems was related to $\alpha$ and $K \mathrm{f}$ as follows,

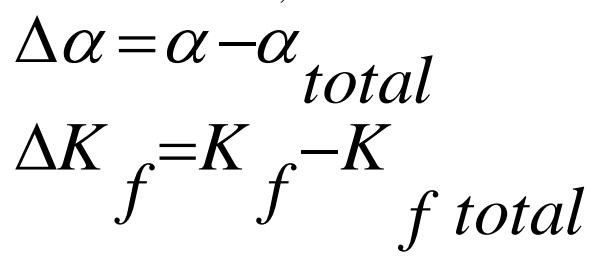


where a, $K_{f}, \alpha_{t}$ ot $a^{\text {and }} K_{\text {total }}{ }^{1}$ are the proton coefficient, mass transfer rate,

theoretical proton coefficient and theoretical mass transfer coefficient, respectively.

The main objective of this work is to determine the effects of mineral mixing on the reactivity and kinetics involved in mercury removal from contaminated water. The sorption kinetic model assumed that sorption rate was determined by sorption interaction between the sorbent reactive sites and the sorbate involving outer sphere complexation and inner sphere complexation [39]. Otherwise, the intra-particle diffusion involving the diffusion of the adsorbate in the pore of the adsorbent as a third sorption reaction step was involved [40]. This is due to the fact that surfaces of clays and hydroxides have a high concentration of $\mathrm{OH}^{-}$groups readily protonated at low $\mathrm{pH}$, generating positive charge which retains anions by electrostatic attraction [41].

The mass balance of $\mathrm{Hg}$ (II) sorbed per unit mass of the mixed mineral suspension $(\mathrm{mg} / \mathrm{g}$ ) was calculated by the following [ 42-44]:

$$
Q_{e}=\langle C i-C e\rangle \frac{V}{W}
$$

where $\mathrm{Ci}$ and $\mathrm{Ce}$ are the initial and equilibrium $\mathrm{Hg}(\mathrm{II})$ concentrations in $\mathrm{mg} / \mathrm{l}, . \mathrm{V}$ is volume of the $\mathrm{Hg}(\mathrm{II})$ solution in $\mathrm{ml}$, and $\mathrm{W}$ is the weight of adsorbent in $\mathrm{mg}$ respectively.

\subsection{System characterization}

\section{Materials and Methods}

Clays used in this study provided by the Richard Baker Harrison Company and Acros Organics Ltd and (hydr)oxides provided by Iconofile Company Inc were nitrogen flushed and stored in airtight containers to avoid surface oxidation. Mercuric chloride $\left(\mathrm{HgCl}_{2}\right)$ provided by Iconofile Company Inc was employed as the source of $\mathrm{Hg}(\mathrm{II})$. .A standard solution containing variable concentrations of $\mathrm{Hg}(\mathrm{II})$ in ppm was prepared by dissolving $\mathrm{HgCl}_{2}$ (Merck) in distilled water. In all experimental studies conducted in triplicates, samples were stored in the dark at room temperature $\left(23 \pm 3{ }^{\circ} \mathrm{C}\right)$ not exceeding $24 \mathrm{~h}$ before analysis [45]. Supernatant was filtered through a cellulose acetate filter (pore size $0.2 \mu \mathrm{m}$ ) and analyzed for $\mathrm{Hg}(\mathrm{II})$ using a Hitachi Atomic Absorption Spectrophotometer (HG-AAS). The working solutions of different concentrations were prepared by diluting the stock solution immediately before starting the batch studies.

For sorbent characterization, the (a) Coulter laser method was used to determine the particle sizes; (b) $\%$ colloid was estimated from the particle size distribution curves; (c) equilibrium $\mathrm{pH}$ of the untreated mineral suspensions was determined using the Model 3340 Jenway ion meter; (d) the standard volumetric Brunauer, Emmett, and Teller (BET) method was used to determine the surface areas [46-47] (e) the Na saturation method was used to determine cation exchange capacity (CEC) of the clay minerals[5] (Table 1). (f) spectral analysis was performed using scanning electron microscopy (SEM ) and energy dispersive spectroscopy (EDS) to confirm the mineral sorbent[48-49].

\subsection{Reactivity experiments}

For reactivity studies to determine the proton coefficient as provided (Eqs. (8), (9), standard laboratory procedure was used [50-51]. 1\% single and 1:1 mixed mineral suspensions with no added electrolyte were reacted with solution containing $10 \mathrm{ppm}$ of arsenite regulated to the required $\mathrm{pH}$ at the start of experiments.

To validate the sorption mechanism involved in mercury removal, $1 \%$ single and 1:1 mixed mineral suspensions made up to $50 \mathrm{ml}$ were reacted with solution containing $10 \mathrm{ppm}$ of $\mathrm{Hg}$ (II) regulated to $\mathrm{pH} 4$. Supernatant was filtered through a cellulose acetate filter (pore size $0.2 \mu \mathrm{m}$ ) and analyzed for $\mathrm{Hg}(\mathrm{II})$, using a Hitachi Atomic Absorption Spectrophotometer (HG-AAS).

Table1: Characteristics of clays and hydrous oxides [49]

\begin{tabular}{|l|l|l|l|l|}
\hline Mineral & $\begin{array}{l}\text { Particle size } \\
(\mu \mathrm{m})\end{array}$ & $\begin{array}{l}\%(<1 \mu \mathrm{m}) \\
\text { colloid }\end{array}$ & $\mathrm{pH} \pm \sigma$ & $\begin{array}{l}\text { Surface } \\
\text { area(SSA } \pm \sigma) \\
\left(\mathrm{m}^{2} / \mathrm{g}\right)\end{array}$ \\
\hline Kaolinite & $20.01 \pm 0.5$ & 3.00 & $6.05 \pm 0.05$ & $47.01 \pm 0.24$ \\
\hline Montmorillonite & $80.05 \pm 0.20$ & 0.53 & $2.01 \pm 0.09$ & $10.00 \pm 0.00$ \\
\hline Goethite & $40.10 \pm 0.15$ & 2.92 & $8.05 \pm 0.06$ & $71.05 \pm 0.17$ \\
\hline Kaolinite/montmorillonite & $80.05 \pm 50$ & 0.97 & $5.01 \pm 0.02$ & $88.05 \pm 0.55$ \\
\hline Montmorillonite/goethite & $15.25 \pm 0.24$ & 3.85 & $3.03 \pm 0.04$ & $147.10 \pm 0.50$ \\
\hline Kaolinite/goethite & $140.35 \pm 55$ & 0.73 & $3.05 \pm 0.01$ & $79.30 \pm 0.59$ \\
\hline
\end{tabular}


Surface charge controls the reactivity of mineral surfaces and is dependent on the acid-base properties of surface hydroxyl groups, where $\mathrm{H}+$ and $\mathrm{OH}^{-}$are the potential-determining ions [26]. Sorption of $\mathrm{Hg}$ (II) on mineral surfaces requires proton exchange, the stoichiometry of this reaction is described [49] and the proton consumption function is given by:

$\alpha \mathrm{SOH}+\mathrm{M}^{2+} \Rightarrow(\mathrm{SOH}) \alpha-\mathrm{M}+\alpha \mathrm{H}+$

$\log \mathrm{Kd}=\log \mathrm{Kp}\{\mathrm{SOH}\} \alpha+\alpha \mathrm{pH}$,

where $\mathrm{SOH}$ is the mineral surface-binding site, $\mathrm{M}^{2+}$ is the soluble metal species, $(\mathrm{SOH}) \alpha-\mathrm{M}$ is the surface bound metal, $\log K \mathrm{p}$ is the apparent equilibrium binding constant, and $\alpha$ is the proton coefficient, representing the number of protons displaced when one mole of metal binds to the mineral surface [[32]. Proton coefficient was calculated from the slope of $\log \mathrm{Kd}$ versus $\mathrm{pH}$ plot (Fig. 2),

\section{Kinetic experiments}

For $\mathrm{Hg}(\mathrm{II})$ removal kinetics experiments, $1 \%$ single and 1:1 mixed mineral systems were reacted with solution containing 10ppm of $\mathrm{Hg}(\mathrm{II})$ regulated to $\mathrm{pH} 4$. Amounts of $\mathrm{Hg}$ (II) remaining in solution after 2, 4, 6, 8, 12, 18, and $24 \mathrm{~h}$ were determined using Hitachi Atomic Absorption Spectrophotometer (HG-AAS). Twenty-four hours was sufficient for kinetic studies because sorption reactions occur in milliseconds or minutes [45, 48]. The transport of adsorbate from external layers to the mineral surface where sorption occurs is dependent on a mass transfer constant $K$ f obtained from the slopes of the curve derived from plotting $C t / C 0$ vs time [34, 49],

$$
\left[\frac{\mathrm{d}\left(\mathrm{C}_{\mathbf{t}} / \mathrm{C}_{\mathrm{O}}\right)}{\mathrm{dt}}\right]_{\boldsymbol{t}=\mathrm{O}} \cong-\mathrm{K}_{\mathrm{r}} \mathrm{ss}
$$

where $C_{t}$ and $C_{0}$ are the initial concentrations of $\mathrm{Hg}(\mathrm{II})$ at time $t, S \mathrm{~s}$ is the exposed external surface area of the sorbent, and $K_{\mathrm{f}}$ is the mass transfer coefficient [42]. The Freundlich isotherm was chosen to describe sorption of $\mathrm{Hg}(\mathrm{II})$ because this is suitable for heterogeneous surfaces over a wide range of solute concentrations [34, 43].

\section{Results And Discussion}

\subsection{Mixed mineral systems and $\mathrm{H}+\mathrm{l}-\mathrm{M}$ exchange stoichiometry}

Although the proton coefficient $(\alpha)$ is not characteristic of a particular mineral (Table 2, derived from Figs.1), differences in $\alpha$ for mixed mineral systems compared to each other and compared to single mineral systems may be linked to differences in the availability of strongly acidic sites All proton coefficient for $\mathrm{Hg}$ (II) sorbed on single mineral systems except for goethite are greater than one. This indicated high level of protonation during the sorption process. Proton coefficient for $\mathrm{Hg}(\mathrm{II})$-kaolinite interaction was higher than $\mathrm{Hg}$ (II) sorbed on goethite and montmorillonite. This may be attributed to the acidic sites present on kaolinite planar surfaces. Significant numbers of weakly acidic edge sites in goethite and montmorillonite may reduce the proton coefficient because of the limited exchange of protons for sorbing ions.

Table2: Proton coefficients $(\alpha)$ and regression coefficient $\left(R^{2}\right)$ of $\mathrm{Hg}(\mathrm{II})$ sorbed on mineral suspensions

\begin{tabular}{|c|c|c|c|}
\hline $\begin{array}{c}\text { Mineral } \\
\text { suspensions }\end{array}$ & $R^{2}$ & $\alpha$ & $\begin{array}{c}\alpha \\
\text { total }\end{array}$ \\
\hline Kaolinite & 0.99 & 1.32 & $\otimes$ \\
\hline Goethite & 0.99 & 0.69 & $\otimes$ \\
\hline Montmorillonite & 0.99 & 1.25 & $\otimes$ \\
\hline Kaolinite/montmorillonite & 0.99 & 0.77 & 1.28 \\
\hline Goethite/kaolinite & 0.99 & 1.24 & 1.00 \\
\hline Goethite/montmorillonite & 0.99 & 1.33 & 0.97 \\
\hline
\end{tabular}

Note: $\otimes$ not applicable 


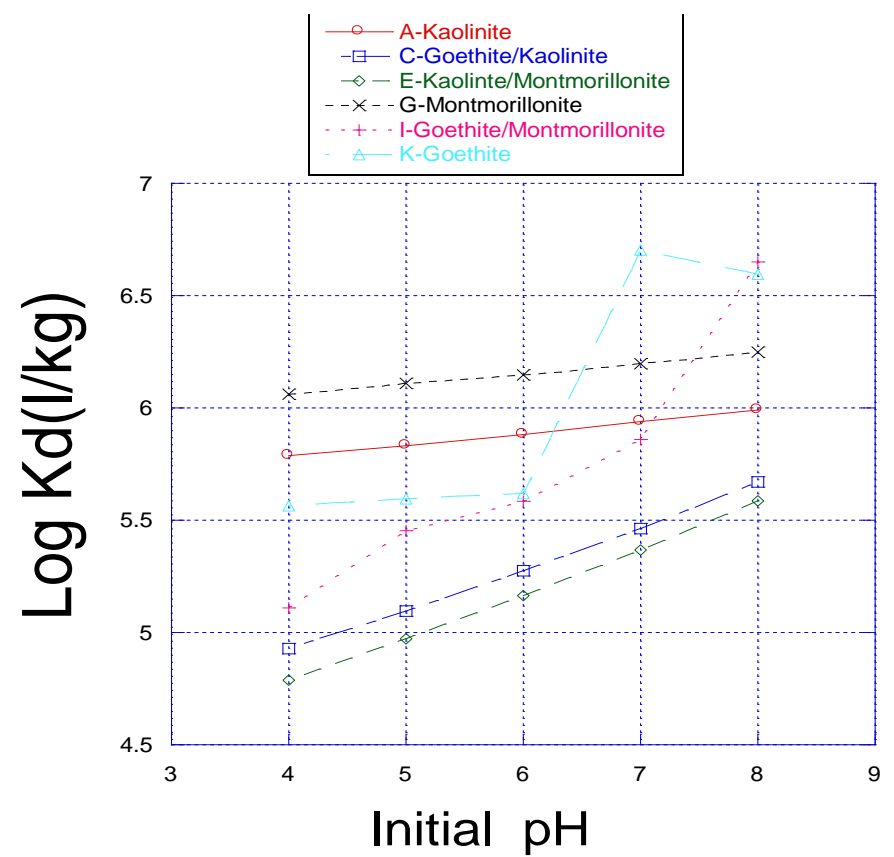

Figure 1: Plots of logKd versus Initial $\mathrm{pH}$ for $\mathrm{Hg}(\mathrm{II})$ sorbed on single and mixed mineral systems.

Except for kaolinite/montmorillonite, mixed mineral suspension, $\alpha_{\text {total }}$ for $\mathrm{Hg}$ (II) sorbed on the mixed mineral suspensions were lower than $\alpha$, indicating attenuated potonation for kaolinite/montmorillonite and enhanced protonation for goethite/kaolinite and goethite/montmorillonite mineral systems. The higher the acidity of sites the more protons are exchanged for $\mathrm{Hg}(\mathrm{II})$. Therefore, mineral mixing reduced the acidity of reactive sites for kaolinite/montmorillonite mixed mineral phase. This may be due to the competition for the sorbing ion by the mixed mineral surfaces [3,34]. The $\mathrm{H}+/-\mathrm{M}$ exchange stoichiometry of <2 (Table 2) for $\mathrm{Hg}$ (II) sorption on both the single and mixed mineral phases agreed with previous findings [32]. This suggested that surface charges became increasingly changed as $\mathrm{Hg}$ (II) sorption progressed. In addition, mineral surfaces with few displaceable $\mathrm{H}+$ with limited $\mathrm{pH}$-dependent sorption supported lower $\mathrm{H}+/-\mathrm{M}$ stoichiometry.
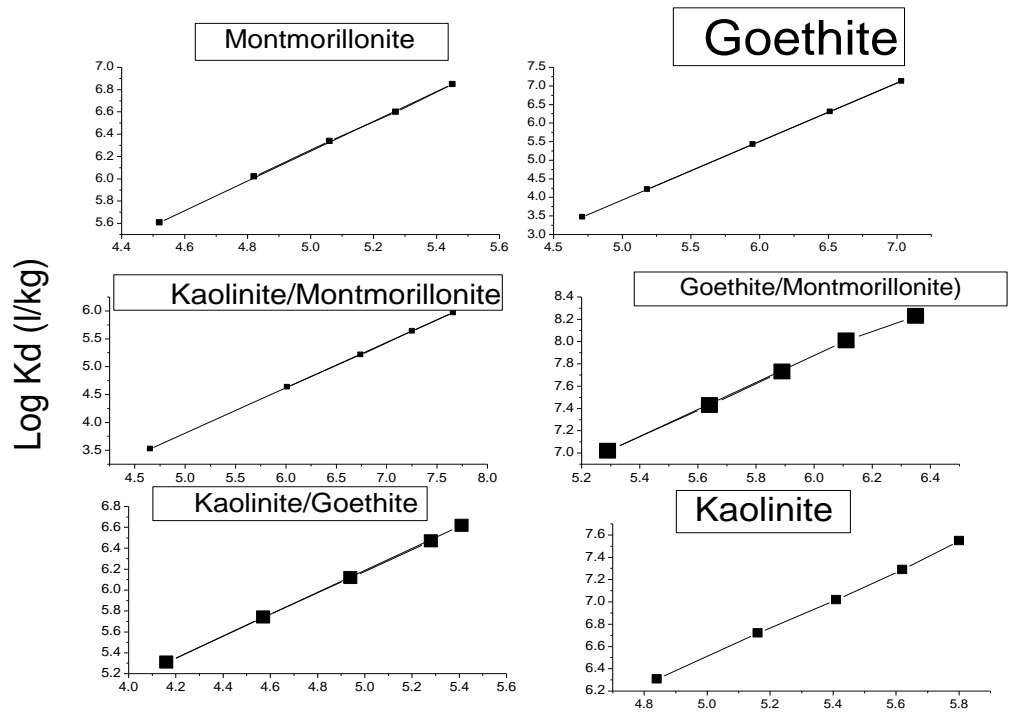

Final $\mathrm{pH}$

Figure 2: Plots of logkd versus Final ph for Hg (II) sorbed on single and mixed mineral systems.

\subsection{Mixed mineral systems and sorption kinetics}

Sorption kinetics indicated a two- phase reaction probably attributed to outer sphere and inner sphere complexation with minimal intra-particle diffusion (Table 3, Fig 3). Mass transfer rate for the first-phase 
reaction $\left(\mathrm{K}_{\mathrm{f}} 1\right)$ decreased in the order goethite $<$ kaolinite<montmorillonite for all single mineral systems. Mixed mineral systems had a decreasing mass transfer rate for montmorillonite-goethite<kaolinitmontmorillonite $<$ kaolinite-goethite. Theoretical mass transfer rates were higher for kaolinite-montmorillonite and montmorillonite-goethite mixed mineral systems. Kaolinite-goethite exhibited a near similar theoretical $\mathrm{K}_{\mathrm{f}} \mathrm{I}$ value when compared with the actual $\mathrm{K}_{\mathrm{f}} \mathrm{I}$ value. This means that mineral mixing based on our empirical model decreased the mass transfer rates for kaolinite-montmorillonite and montmorillonite-goethite, not affecting kaolinite-goethite. For $\mathrm{K}_{\mathrm{f}} \mathrm{II}$ depicting the second-phase reaction, mass transfer rates decreased in the order, goethite $<$ kaolinite $<$ montmorillonite for the single mineral phases. For the mixed mineral systems, the order was, montmorillonite-goethite<kaolinite-goethite<kaolinite-montmorillonite. Based on the empirical model, mineral mixing did not change the mass transfer rates for the mixed mineral systems except for montmorillonitegoethite. There was a decrease in the mass transfer rate for montmorillonite-goethite. This is because the theoretical mass transfer rate for this mixed mineral system was higher than the actual mass transfer rate.

Differences in mass transfer rates for $\mathrm{Hg}$ (II) ions transferred to the mineral reactive sites may be attributed (a) to different types of reactive sites on the single and mixed mineral systems (b) differences in BET surface area for the mineral systems [Fig 4] and (c) differences in particle size distribution of these mineral systems [6].

Table 3: Mass transfer rates for $\mathrm{Hg}(\mathrm{II})$ sorbed on clay and (hydr)oxide mineral suspensions

\begin{tabular}{|c|c|c|c|c|c|c|}
\hline $\begin{array}{l}\text { Parameters/ } \\
\text { Mineral }\end{array}$ & 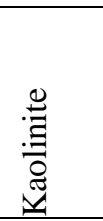 & 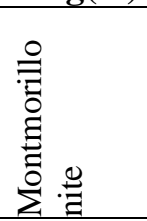 & 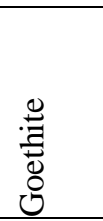 & 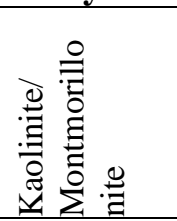 & 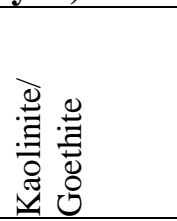 & 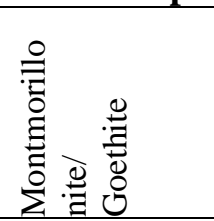 \\
\hline slopeI $\left(\mathrm{hr}^{-1}\right)$ & -0.07 & -0.14 & 0.088 & -0.062 & -0.104 & -0.097 \\
\hline slopeII $\left(\mathrm{hr}^{-1}\right)$ & $\overline{0}-006$ & -0.011 & $\begin{array}{l} \\
\end{array}$ & -0.058 & -0.0083 & -0.0075 \\
\hline $\begin{array}{l}\text { Exposed Surface } \\
\text { Area } \\
\left(\mathrm{cm}^{-1}\right)\end{array}$ & 4700 & 1000 & 7100 & 8800 & 7900 & 14700 \\
\hline $\mathrm{K}_{\mathrm{f}} \mathrm{I}\left(\mathrm{cmhr}^{-1}\right)$ & $\begin{array}{l}1.49 \\
*-5 \\
\end{array}$ & 0.00014 & $\begin{array}{l}1.24 \\
*-5 \\
\end{array}$ & $7.04 *-6$ & $1.31 *-5$ & $6.6 *-6$ \\
\hline $\begin{array}{l}\text { Theoretical } \mathrm{K}_{\mathrm{f}} \mathrm{I} \\
\left(\mathrm{cmhr}^{-1}\right)\end{array}$ & 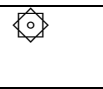 & $\Leftrightarrow$ & $\Leftrightarrow$ & 0.00007745 & 0.00001365 & 0.000082 \\
\hline $\mathrm{K}_{\mathrm{f}} \mathrm{II}\left(\mathrm{cmhr}^{-1}\right)$ & $\begin{array}{l}1.28 \\
*-6\end{array}$ & 0.000011 & $\begin{array}{l}9.85 \\
*-7\end{array}$ & $6.6 *-6$ & $1.05 *-6$ & $5.1 *^{-7}$ \\
\hline $\begin{array}{l}\text { Theoretical } \mathrm{K}_{\mathrm{f}} \mathrm{II} \\
\left(\mathrm{cmhr}^{-1}\right)\end{array}$ & $\Leftrightarrow$ & $\Leftrightarrow$ & $\Leftrightarrow$ & 0.00000614 & 0.00000113 & 0.0000059925 \\
\hline
\end{tabular}

Note: Not applicable
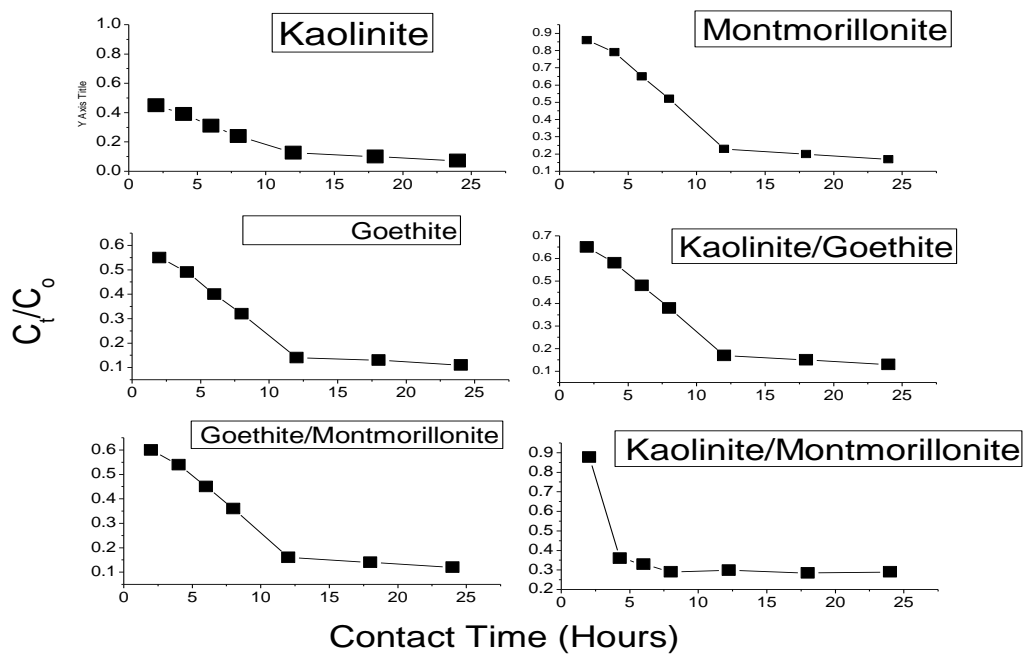

Fig. 3. Effects of $\mathrm{Hg}(\mathrm{II})$ sorption on mass transfer rates for single and mixed mineral systems 


\subsection{Mixed mineral systems and $\mathrm{Hg}(\mathrm{II})$ removal}

The mercury uptake decreased as BET surface area increased for all single and mixed mineral systems within the range of $\mathrm{pH}$ studied. Furthermore, the mercury uptake does not appear to be linearly correlated with BET surface area, implying that mercury sorption onto single and mixed mineral systems is not strictly a surface phenomenon [30]

Mercury sorption exhibited a sinusoidal pattern probably attributed to outer sphere, inner sphere complexation and minimal intra-particle diffusion (Fig 5). All mineral systems demonstrated increase in \% sorption at the onset of reaction, indicating a reaction dip after 6 hours of contact or residence time for kaolinite and kaolinite-montmorillonite. Goethite, goethite-montmorillonite and kaolinite-goethite exhibited a reaction dip at $12 \mathrm{~h}$ residence time. There appeared to be no significant change in mercury sorption for these mineral systems after $12 \mathrm{~h}$ contact time. Montmorillonite exhibited an astronomical Hg removal at the onset of reaction, experiencing a reaction dip after $8 \mathrm{~h}$ contact time, then progressively decreased for the rest of the contact time. Differences in mercury removal as exhibited by these mineral systems could be attributed to differences in BET surface area (Table 1, Fig 4). Differences between actual and theoretical \% sorption progressed from negative to positive for all mixed minerals as contact time was increased. This means that increase in contact time during $\mathrm{Hg}$-sorbent interaction could help increase mercury removal based on mineral mixing (Fig 6).

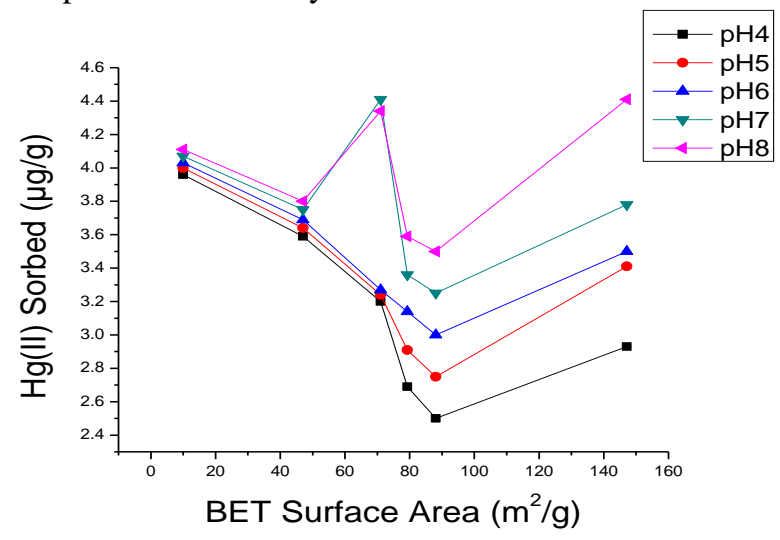

Figure 4: Plot of $\mathrm{Hg}$ (II) Sorbed vs. BET Surface area of clays and hydroxides [Table 1] at variable pH

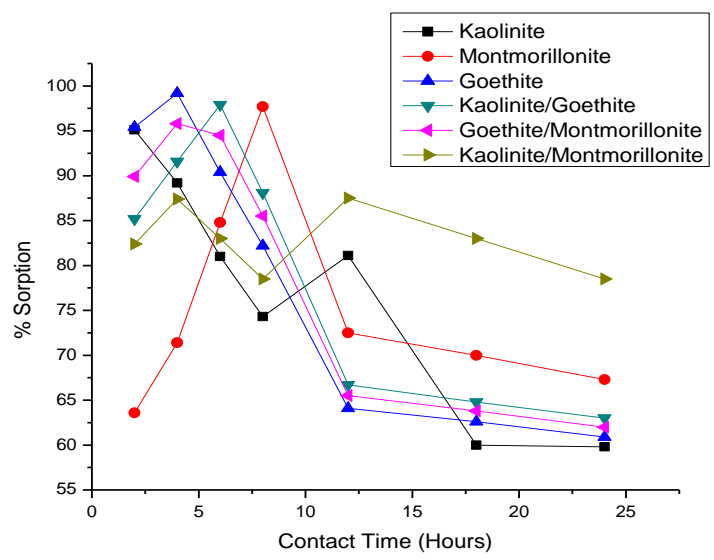

Fig.5. Plots of $\mathbf{H g}(\mathrm{II}) \%$ sorption vs. time (hours) for single and mixed mineral systems. 


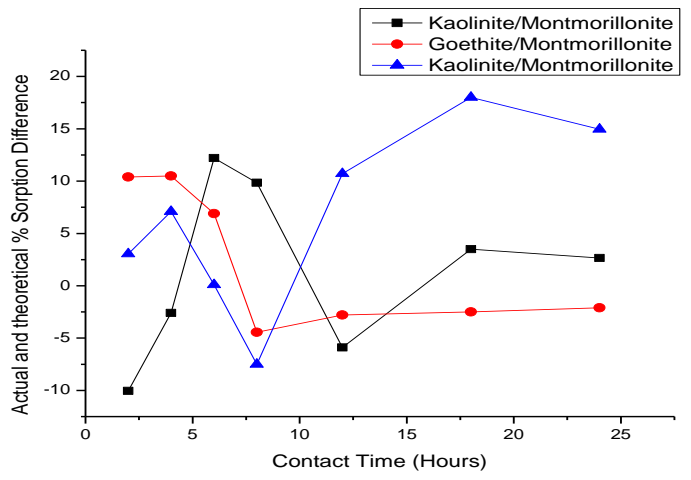

Fig. 6: Plots of differences between actual percent of $\mathrm{Hg}$ (II) removal and Theoretical percent vs. contact time (hours) for mixed mineral systems.

\section{Conclusions}

The reactivity and removal kinetics of $\mathrm{Hg}(\mathrm{II})$ treated with single and mixed mineral systems of kaolinite, montmorillonite and goethite have been investigated. Using empirical models derived from Freundlich isotherm model, proton coefficient for mercury sorbed on All proton coefficient for $\mathrm{Hg}$ (II) sorbed on single mineral systems except for goethite are greater than one. This indicated high level of protonation during the sorption process. Except for kaolinite/montmorillonite, mixed mineral suspension, $\alpha_{\text {total }}$ for $\mathrm{Hg}$ (II) sorbed on the mixed mineral suspensions were lower than $\alpha$, indicating attenuated potonation for kaolinite/montmorillonite and enhanced protonation for goethite/kaolinite and goethite/montmorillonite mineral systems.

Mass transfer rate for the first-phase reaction $\left(\mathrm{K}_{\mathrm{f}} 1\right)$ decreased in the order goethite <kaolinite<montmorillonite for all single mineral systems. Mixed mineral systems had a decreasing mass transfer rate for montmorillonite-goethite<kaolinit-montmorillonite<kaolinite-goethite. This suggested that different reactive sites were involved in the removal kinetics of the sorbing ions as sorption progressed. Differences in sorption kinetics between the single and mixed mineral phases may be attributed to differences in the BET surface area of single and mixed mineral systems. All mineral systems demonstrated increase in $\%$ sorption at the onset of reaction, indicating a reaction dip after 6 hours of contact or residence time for kaolinite and kaolinite-montmorillonite. Goethite, goethite-montmorillonite and kaolinite-goethite exhibited a reaction dip at $12 \mathrm{~h}$ residence time. Differences between actual and theoretical \% sorption progressed from negative to positive for all mixed minerals as contact time was increased. This means that increase in contact time during $\mathrm{Hg}$-sorbent interaction could help increase mercury removal based on mineral mixing.

\section{References}

[1]. Pavlish JH, Holmes MJ, Benson SA, Crocker CR, Galbreath KC. 2004, Application of sorbents for mercury control for utilities burning lignite coal. Fuel Process Technol; 85:563-76.

[2]. Directive 2000/60/EC. Water Framework Directive of the European Parliament and of the Council of 23 October, 2000.

[3]. Zhang, F.-S Nriagu, J.O. Itoh, H. 2005, Mercury removal from water using activated carbons derived from organic sewage sludge, Water Res. 39, 389-395.

[4]. Kitano, Y. Okumura, M. Idogaki, M. 1980, Abnormal behaviour of $\mathrm{Cu} 2+$ and $\mathrm{Zn}$ ions in parent solution at the early stage of calcite formations. Geochem. J. 14 167-175.

[5]. Bhakta, J. N. Salim, Md Yamasaki K. Munekage, Y. 2009, mercury adsorption stoichiometry of ceramic and activated carbon from aqueous phase under different $\mathrm{pH}$ and temperature, arpn journal of engineering and applied sciences 4, 52-59.

[6]. Zhao Y, Xue, F., Ma T., 2013, Experimental study on Hg0 removal by diperiodatocuprate (III) coordinationion solution, Fuel Processing Technology 106 468-473,

[7]. Eric, B. Selma L., Ronald, L. 2010, Fishing activity, health characteristics and mercury exposure of Amerindian women living alongside the Beni river (Amazonian Bolivia), International Journal of Hygiene and Environmental Health 213.

[8]. Stephan, B McCarty, K.M. Nadine, S. . Beate, L 2010, Mercury exposure and children's health, Current Problems in Pediatric and Adolescent Health Care 40 186-215.

[9]. Dastoora AP, Larocpue Y. Global circulation of atmospheric mercury: a modeling study. Atmos Environ 2004; 38:147-61

[10]. Deshicar, A.M.. Bokade, S.S Dara, S.S. 1990, Modified hardwickia binata bark for adsorption of mercury (II) from water, Water Res. 24, 1011-1016.

[11]. USEPA, 2001, National Primary Drinking Water Standards; EPA 816-F-01-007 http://www.epa.gov/safewater

[12]. Dzombak, D.A. Morel, F. 1990, Surface Complexation Modeling: Hydrous Ferric Oxide, Wiley, New York,

[13]. Lopez-Mũnoza, M.J. Aguadoa, J. Arencibiab, A Pascuala. R. 2011, Mercury removal from aqueous solutions of $\mathrm{HgCl}_{2} \mathrm{by}$ heterogeneous photocatalysis with TiO2 Applied Catalysis B: Environmental 104, 220-228.

[14]. Hatje, V.H. Hill, D.M. McOrist, G. Birch, G.F. Szymczak, R. 2003, Kinetics of trace element uptake and release by particles in estuarine waters: effects of $\mathrm{pH}$, salinity, and particle loadin J. Environ. Int. 29, 613-618.

[15]. Reichenberg, D. 1952, Properties of ion exchange resins in relation to their structure. III. Kinetics of exchange, J. Am. Chem. Soc. 75, 589-598.

[16]. Kitano, Y. Okumura, M. Idogaki, M. 1980, Abnormal behaviour of $\mathrm{Cu} 2+$ and $\mathrm{Zn}$ ions in parent solution at the early stage of calcite formations. Geochem. J. 14 167-175. 
[17]. Ravichandran, M., 2004. Interactions between mercury and dissolved organic matter - a review. Chemosphere 55, 319-331.

[18]. Guedron S., Cossa D., Grimaldi M., Charlet L., 2011, Methylmercury in tailings ponds of Amazonian gold mines (French Guiana): Field observations and an experimental flocculation method for in situ remediation Applied Geochemistry 26, 222-229.

[19]. Trasande L, Landrigan PJ, Schechter C. 2005, Public health and economic consequences of methyl Hg toxicity to the developing brain, Environ Health Perspect;113:590-6.

[20]. Santra, M. Ryu, D. Chatterjee, A. Ko, S.-K. Shin I., Ahn, K.H. 2009, A chemodosimeter approach to fluorescent sensing and imaging of inorganic and methylmercury species, Chem. Commun. 2115-2117.

[21]. Yang H, Xu Z, Fan M, Bland A, Judkins R. 2007, Adsorbents for capturing mercury in coal-fired boiler flue gas. J Hazard Mater; $146: 1-11$.

[22]. Wang, H Chan, W.-H. 2007, Cholic acid-based fluorescent sensor for mercuric and methyl mercuric ion in aqueous solutions, Tetrahedron 63, 8825-8830.

[23]. Chen, X. . Kim, S.-W Jou, M.J. Kim, YKim, S. Park, . S.-J. Yoon, J. 2008, $\mathrm{Hg}^{2+}$ selective fluorescent and colorimetric sensor: its crystal structure and application to bioimaging, Org. Lett. 105235-5238.

[24]. Ko, S.-K.. Yang, Y.-K Tae, J. Shin, I. 2006, In vivo monitoring of mercury ions using a rhodamine-based molecular probe, J. Am. Chem. Soc. 128, 14150-14155.

[25]. Yang, Y.-K. Ko, S.-K. Shin, I. Tae, J. 2009, Fluorescent detection of methylmercury by desulfurization reaction of rhodamine hydrazide derivatives, Org. Biomol. Chem. 7, 4590-4593.

[26]. Tan, Z, Qiu, J Zeng, H. Liu, H. Xiang J. 2011, Removal of elemental mercury by bamboo charcoal impregnated with H2O2, Fuel 90, 1471-1475

[27]. Olivaa J., De Pablob, J., Cortinab, J-L., Camad, J., Ayorad C., 2011, Removal of admium, copper, nickel, cobalt and mercury from water by Apatite IITM: Column experiments, Journal of Hazardous Materials 194, 312-323

[28]. Luo G Maa, J Han J Yao H., Xu M., Zhang C., Chen G., Gupta R., , Xu Z., 2013, Hg occurrence in coal and its removal before coal utilization, Fuel 104 70-76.

[29]. Wang. Z. Wu. D. Wu. G. Yang. N. Wu. A. 2013, Modifying Fe3O4 microspheres with rhodamine hydrazide for selective detection and removal of $\mathrm{Hg} 2+$ ion in water, Journal of Hazardous Materials 244-245, 621-627.

[30]. Anagnostopoulos V. A. Manariotis I. D. . Karapanagioti H. K Chrysikopoulos C. V. 2012, Removal of mercury from aqueous solutions by malt spent rootlets, Chemical Engineering Journal 213, 135-141.

[31]. Ghoshal, S., Bhattacharya, P., Chowdhury R., 2011, De-mercurization of wastewater by Bacillus cereus (JUBT1): Growth kinetics, biofilm reactor study and field emission scanning electron microscopic analysis Journal of Hazardous Materials 194, 355-361

[32]. Kooner Z.S. 1993, Comparative study of adsorption behavior of copper, lead, and zinc onto goethite in aqueous systems. Environ. Geol. 21, 242-250.

[33]. Muresan B. Pernet-Coudrier B. Cossa D. Varrault G. 2011, Measurement and modeling of mercury complexation by dissolved organic matter isolates from freshwater and effluents of a major wastewater treatment plant Applied Geochemistry 26, $2057-2063$.

[34]. Deshicar, A.M.. Bokade, S.S Dara, S.S. 1990, Modified hardwickia binata bark for adsorption of mercury (II) from water, Wat er Res. 24, 1011-1016

[35]. Cataldo S., Gianguzza A., , Pettignano A., Villaescusa I., 2013, Mercury(II) removal from aqueous solution by sorption onto alginate, pectate and polygalacturonate calcium gel beads. A kinetic and speciation based equilibrium study, Reactive \& Functional Polymers 73 207-217

[36]. Ionics 101- Zheng Y. Jensen A. D. Windelin C. Jensen F. 2012, Review of technologies for mercury removal from flue gas from cement production processes Progress in Energy and Combustion Science 38, 599

[37]. O” zcan A.; O“ ncu“ E.M.; O” zcan, A.S. 2006, Kinetics, isotherm and thermodynamic studies of adsorption of Acid Blue 193 from aqueous solutions onto natural sepiolite. Colloids and Surfaces A: Physicochemical and Engineering Aspects, $277,90-97$.

[38]. Egirani DE, Baker AR, Andrews JE 2005b, Copper and zinc removal from aqueous solution by mixed mineral systems II: The role of solution composition and aging. Journal of Colloid and Interface Science 291, 326-333.

[39]. Tombacz E. Filipcseis, G. Szekeres, M. Gingl, Z. 1999, Particle aggregation in complex aquatic systems J. Colloids Surf. 15 233244 .

[40]. Blesa M.A. Magaz G. Salfity J.A. \& Weisz, A.D 1997, Structure and reactivity of colloidal metal particles immersed in water. Solid State 103, 1235-1241.

[41]. McBride M.B. 1982, Organic anions adsorption on aluminum hydroxides: spin probe studies,. Clay and clay minerals, 30(4), 438444.

[42]. Al-Degs, Y.S. Tutunji, M.F. Baker, H.M 2003, Isothermal and kinetic adsorption behaviour of Pb“ ions on natural silicate minerals J. Clay Miner. 38 501-509.

[43]. McLean, J.E. Bledsoe, B.E 1992, Behaviour of Metals in Soils, U.S. Environmental Protection Agency, Washington, DC.

[44]. Altun, T., \& Pehlivan, E. 2012, Removal of Cr(VI) from aqueous solutions by modified walnut shells. Food Chemistry, 132, 693700 .

[45]. Morton J.D Semaru J.D. Hayes K.F. 2001, An X-ray absorption spectroscopy study of the structure and reversibility of copper adsorbed to montmorillonite clay, Geochim. Cosmochim. Acta 65, 2709-2722.

[46]. Brunauer, S. Emmett, P.H. Teller, E. 1938, Adsorption of gases in multimolecular layers, J. Am. Chem. Soc. 60, 309-319.

[47]. Hlavay, J., \& Polyak, K. 2005, Determination of surface properties of ironhydroxide-coated alumina adsorbent prepared for removal of arsenic from drinking water. Journal of Colloid and Interface Science, 284, 71-77.

[48]. Ravenna L. 1993, Final Burial or Potential Remobilization Water Sci. Technol., 28, 349-358.

[49]. 629. 